\title{
Nano-Toxicity: A Bird's Eye View of Toxicological Aspects
}

\author{
Anju Mangotra ${ }^{1}$ and R S Sai Murali ${ }^{2 *}$ \\ ${ }^{1}$ Department of Bioengineering and Biosciences, India \\ ${ }^{2}$ Division of Research and Development, India \\ *Corresponding author: R S Sai Murali, Division of Research and Development, India,
}

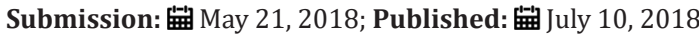

\section{Introduction}

Every technology has to face exaltation and disparagement at various levels. Strengths of a technology are readily translated into functional outcomes while the shortcomings pave way for further research and breakthroughs. Nanotechnology is not an exception from this clause. With the growing prominence this technology is facing major setbacks. One such setback is associated toxicity. In this paper, we confine ourselves to present potential toxic effects of nanoparticles. The bird's eye view of this problem may help develop strategies for using these materials in various applications.

Nanomaterials have changed our approach towards research and development expanding the horizons of frontiers in science and technology (Figure 1). Many argue on the threat that nanoparticles could possibly confer on humans and ecosystems [1]. Though this argument has some experimental evidence, it is possible that such arguments are often farfetched assumptions. As enquiry and evidence form basis for empirical science, a thorough investigation on the probable negative implications of nanomaterials on humans and ecosystems may provide guidance for technology development using these materials. Tiny size of nanoparticles (NPs) may facilitate their easy entry into the human, animal and plant bodies. It has been reported that the size of the NPs are proportional to the toxicity they cause [2,3]. The aluminium oxide NPs are widely used in several clinical applications [4]. Recent studies report DNA toxicity of aluminium oxide NPs without any mutagenic effects [3]. Copper NPs cause liver, spleen and kidney impairment [3]. Under controlled experimental conditions Copper oxide NPs also caused gill lesions to common carp (Cyprinus carpio L.) leading to reduced survival rates [5]. Similarly, phytotoxicity of Copper oxide NPs has been observed in Phaseolus radiatus and Triticum aestivum [1].

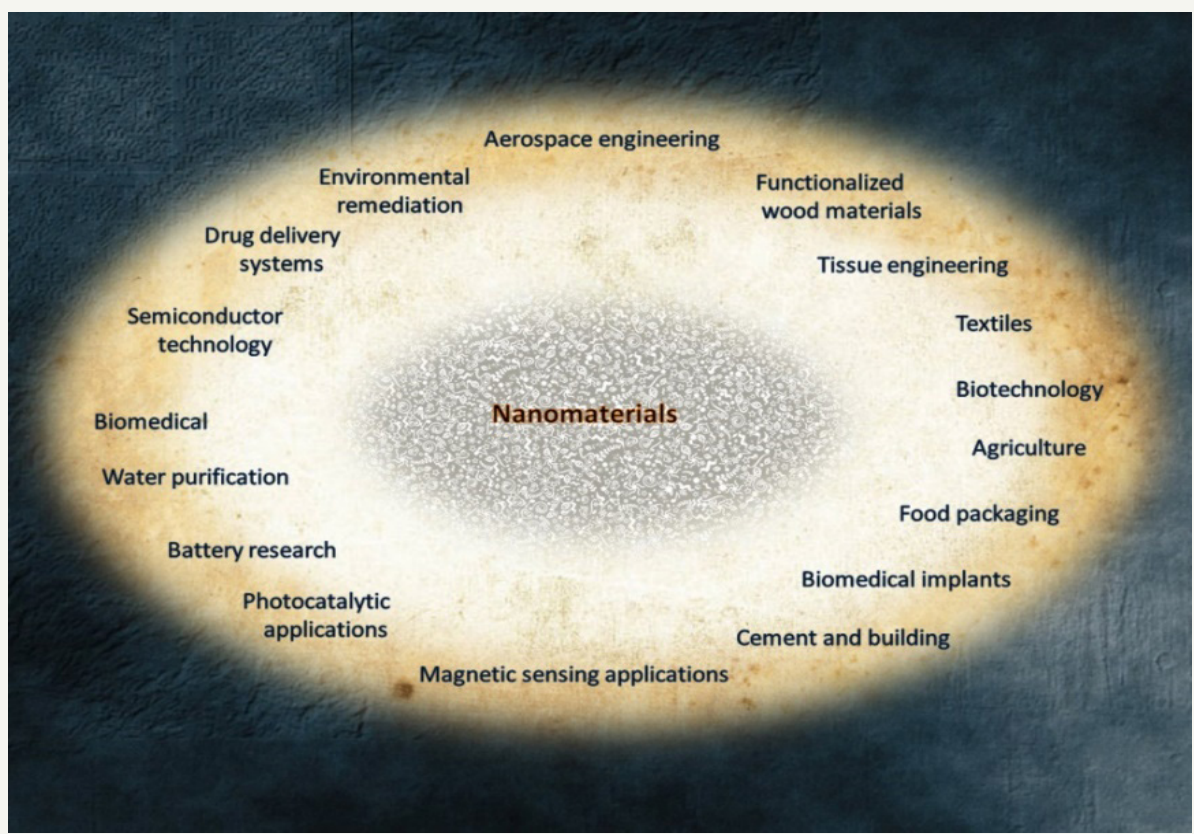

Figure 1: Application of nanomaterials in the research and development. 
However, the toxic properties associated with copper NPs are used in developing antimicrobial agents [6]. Silver NPs elicit cytotoxicity leading to reduced cell viability, increased generation of reactive oxygen species and lactase dehydrogenase [3]. Additionally, Silver NPs oxidize intermediary metabolites and damage cell membrane, disrupt ATP production and DNA replication [7]. Toxic effect of mannitol- modified silver NPs at the concentration of $50 \mathrm{mgL}^{-1}$ has been reported in Drosophila melangoster [7]. Silver NPs pose a significant hazard on marine life too [8]. Irrespective of the toxic effects of Silver NPs, researchers use them in devising sensors with increased precision and working [9]. Similarly, zinc oxide NPs cause cell membrane damage and increase oxidative stress [3]. Zinc oxide NPs are equally toxic; both in bulk and nano formulations [10]. ZNO NPs are considered toxic followed by $\mathrm{CuO}$ NPs and $\mathrm{TiO}_{2} \mathrm{NPs}$ as per reports $[10,11]$. With the increase in the concentration of $\mathrm{ZnO}$ NPs, the survival capacity of Daphania magna has been reported to decrease [1]. However, ZnO NPs are extensively used in textile industry and U.V. shielding [12].

Despite the advanced applications in chemotherapy and MRI $[13,14]$, Iron Oxide NPs show prominent accumulation in the vital organs of the human body [3]. Titanium oxide NPs used in electrode of desensitized solar cells [15] cause DNA damage and lung inflammation in animals [3]. $\mathrm{Al}_{2} \mathrm{O}_{3}, \mathrm{SiO}_{2}$ and $\mathrm{ZnO}$ nanoparticles have bactericidal effects [11]. Renal toxicity has been observed with NPs of Cadmium sulphide in rats [16]. Polystyrene NPs get accumulated in the yolk sac as early as $24 \mathrm{hrs}$ and then migrate to vital organs resulting in reduced heart rate and general functioning [17]. Even though carbon based multi-walled nanotubes are extensively used in various technologies, they cause carcinogenic effect in animals [3]. Silica NPs used in biosensors show mitochondrial damage leading to oxidative stress [3]. Negative impacts of Nanoparticles have been observed on the Environment as well. Toxic effects of NPs have been observed on microalgae $[1,18]$. NPs have interfered with the removal of COD, nitrogen and phosphorus by $\mathrm{CuO}, \mathrm{ZnO}$ and $\mathrm{TiO}_{2}$, and thereby with the efficiency in remediation [18]. The higher concentrations of $\mathrm{TiO}_{2}$ cause decrease in the density of algae [19]. Graphene oxide NPs cause lethality, free radical formation, reduction on feeding rates and accumulation on alimentary gut of Ceriodaphania dubia [20]. The kinetics and extent of $\mathrm{TiO}_{2} \mathrm{NP}$ adsorption on algae depends highly on $\mathrm{pH}$ [10]. The toxicity of $\mathrm{TiO}_{2}$ has been reported in Artemia and Algal cells [2]. The impairment in the physiological intestinal functioning of Zebra fish has been reported on exposure to $\mathrm{TiO}_{2} \mathrm{NPs}$ and biphenol A [21]. Aluminium oxide NPs have been reported to exhibit negative influence on root length, biomass and leaf count of the seedlings in Nicotiana tabacum [22]. Toxicity of nanoparticles has been reported in Raphanus sativus, Brassica napus, Lolium multiflorum, Lactuca sativa, Zea mays and Cucumis sativis [23]. On exposure to zinc oxide NPs, rye grass showed decrease in biomass, increased vacuolated epidermis and cortical cells of roots [24]. There has been a decreased survival rates with the increased exposure to copper NPs in Phaseolus radiates and Triticum aestivum [23]. Silver NPs pose a significant hazard on marine life [8]. Ag NPs are proved to be more toxic as compared to soluble silver in case of bacteria [25]. Titanium oxide NPs have been reported to elicit greater toxicity in bacteria Bacillus subtilis, Escherichia coli and Pseudomonas fluorescens [11].

\section{Conclusion}

In conclusion, there is no technology without some degree of adverse effects. Hence, a methodical scheme has to be developed to check the potential implications of nanomaterials on humans and ecosystems. So far, the past reports are scattered and lack uniformity in the experimental setup and rational enquiry. Guidelines for carrying out research on toxicity assessment of nanomaterials on various organisms have to be scrupulously followed in the assessment of nano-toxicity. The negative connotation attached with nanomaterials may need to be relooked and proper awareness has to be created among laymen and researchers. Follow up mechanisms based on empirical toxicological evidence may need to be taken up to further the development of technologies based on nanomaterials.

\section{References}

1. Lee WM, An YJ, Yoon H, Kweon HS (2008) Toxicity and bioavailability of copper nanoparticles to the terrestrial plants mung bean (Phaseolus radiatus) and wheat (Triticum aestivum): plant agar test for waterinsoluble nanoparticles. Environ Toxicol Chem 27(9): 1915-1921.

2. Bhuvaneshwari $M$, Thiagarajan $V$, Nemade $P$, Chandrasekaran $N$, Mukherjee A (2018) Toxicity and trophic transfer of P25 Ti02 NPs from Dunaliella salina to Artemia salina: Effect of dietary and waterborne exposure. Environ Res 160: 39-46.

3. Bahadar H, Maqbool F, Niaz K, Abdollahi M (2016) Toxicity of nanoparticles and an overview of current experimental models. Iran Biomed J 20(1): 1-11.

4. Mukherjee A (2011) Antimicrobial activity of aluminium oxide nanoparticles for potential clinical applications. Science against microbial pathogens: communicating current research and technological advances 1: 245-251.

5. Vajargah MF, Yalsuyi AM, Hedayati A, Faggio C (2018) Histopathological lesions and toxicity in common carp (Cyprinus carpio L. 1758) induced by copper nanoparticles. Microsc Res Tech 81(7): 724-729.

6. Ren G, Hu D, Cheng EW, Vargas-Reus MA, Reip P (2009) Characterisation of copper oxide nanoparticles for antimicrobial applications. Int J Antimicrob Agents 33(6): 587-590.

7. Sharma VK, Siskova KM, Zboril R, Torresdey GJL (2014) Organic-coated silver nanoparticles in biological and environmental conditions: fate, stability and toxicity. Adv Colloid Interface Sci 204: 15-34.

8. Ellis LA, Baalousha M, Jones EV, Lead JR (2018) Seasonal variability of natural water chemistry affects the fate and behaviour of silver nanoparticles. Chemosphere 191: 616-625.

9. Luo X, Morrin A, killard AJ, Smyth MR (2006) Application of nanoparticles in electrochemical sensors and biosensors. Electroanalysis 18(4): 319326.

10. Aruoja V, Dubourguier HC, Kasemets K, Kahru A (2009) Toxicity of nanoparticles of $\mathrm{CuO}, \mathrm{ZnO}$ and $\mathrm{TiO}_{2}$ to microalgae Pseudokirchneriella subcapitata. Sci Total Environ 407(4): 1461-1468.

11. Jiang W, Mashayekhi H, Xing B (2009) Bacterial toxicity comparison between nano-and micro-scaled oxide particles. Environ Pollut 157(5): 1619-1625. 
12. Becheri A, Dürr M, Nostro PL, Baglioni P (2008) Synthesis and characterization of zinc oxide nanoparticles: application to textiles as UV-absorbers. Journal of Nanoparticle Research 10(4): 679-689.

13. Mahmoudi M, Sant S, Wang B, Laurent S, Sen T (2011) Superparamagnetic iron oxide nanoparticles (SPIONs): development, surface modification and applications in chemotherapy. Adv Drug Deliv Rev 63(1-2): 24-46.

14. Qiao R, Yang C, Gao M (2009) Superparamagnetic iron oxide nanoparticles: from preparations to in vivo MRI applications. Journal of Materials Chemistry 19(35): 6274-6293.

15. Jung HS, Lee JK, Nastasi M, Lee SW, Kim JY, et al. (2005) Preparation of nanoporous $\mathrm{MgO}$-coated $\mathrm{TiO}_{2}$ nanoparticles and their application to the electrode of dye-sensitized solar cells. Langmuir 21(23): 10332-10335.

16. Rana K, Verma Y, Rani V, Rana SVS (2018) Renal toxicity of nanoparticles of cadmium sulphide in rat. Chemosphere 193: 142-150.

17. Pitt JA, Kozal JS, Jayasundara N, Massarsky A, Trevisan R, et al. (2018) Uptake, tissue distribution, and toxicity of polystyrene nanoparticles in developing zebrafish (Danio rerio). Aquat Toxicol 194: 185-194.

18. Zhang X, Zhou Y, Xu T, Zheng K, Zhang R, et al. (2018) Toxic effects of $\mathrm{CuO}, \mathrm{ZnO}$ and $\mathrm{TiO}_{2}$ nanoparticles in environmental concentration on the nitrogen removal, microbial activity and community of Anammox process. Chemical Engineering Journal 332: 42-48.

19. Wright MV, Matson CW, Baker LF, Castellon BT, Watkins PS (2018) Titanium dioxide nanoparticle exposure reduces algal biomass and alters algal assemblage composition in wastewater effluent-dominated stream mesocosms. Sci Total Environ 626: 357-365.
20. Souza JP, Venturini FP, Santos F, Zucolotto V (2018) Chronic toxicity in Ceriodaphnia dubia induced by graphene oxide. Chemosphere 190: 218224.

21. Chen L, Guo Y, Hu C, Lam PKS, Lam JCW, et al. (2018) Dysbiosis of gut microbiota by chronic coexposure to titanium dioxide nanoparticles and bisphenol A: Implications for host health in zebrafish. Environ Pollut 234: 307-317.

22. Burklew CE, Ashlock J, Winfrey WB, Zhang B (2012) Effects of aluminum oxide nanoparticles on the growth, development, and microRNA expression of tobacco (Nicotiana tabacum). PloS one 7(5): e34783.

23. Monica RC, Cremonini R (2009) Nanoparticles and higher plants. Caryologia 62(2): 161-165.

24. Lin D, Xing B (2008) Root uptake and phytotoxicity of ZnO nanoparticles. Environ Sci Technol 42(15): 5580-5585.

25. Buffet PE, Zalouk-Vergnoux A, Châtel A, Berthet B, Métais I, et al. (2014) A marine mesocosm study on the environmental fate of silver nanoparticles and toxicity effects on two endobenthic species: the ragworm Hediste diversicolor and the bivalve mollusc Scrobicularia plana. Science of the Total Environment Sci Total Environ 470-471: 1151-1159.

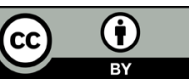

Creative Commons Attribution 4.0 International License

For possible submissions Click Here
Submit Article

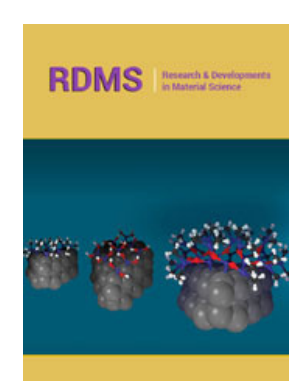

Research \& Development in Material Science

\section{Benefits of Publishing with us}

- High-level peer review and editorial services

- Freely accessible online immediately upon publication

- Authors retain the copyright to their work

- Licensing it under a Creative Commons license

- Visibility through different online platforms 